\title{
GENERALS DE GAULLE, DUMITRESCU AND HERUVIM, GRADUATES OF SAINT-CYR
}

\author{
Gabriel Ion Degeratu ${ }^{1}$ \\ Valahia University Târgovişte
}

\begin{abstract}
A very important Romanian historical event took place on 14 May 1968 when General Charles de Gaulle, the president of The French Fifth Republic, visited Bucharest, an initiative stemming from this visionary head of state's idea of a unified Europe stretching 'from the Atlantic to the Urals'. Have you heard of Romanian generals Polihron Dumitrescu and loan Heruvim? Charles de Gaulle's visit proved quite difficult to manage for the communist regime, one of the difficulties being the French general's meeting with these two generals, former classmates from the Special Military School of Saint-Cyr. His itinerary included the cities of Craiova and Târgoviște because of these expectedly emotional meetings with Dumitrescu and Heruvim, the former having been de Gaulle's class president, and the latter one of its most brilliant students, and the city of Cetatea Băniei where the French general performed an official military salute.
\end{abstract}

Keywords: General Charles de Gaulle; General Polihron Dumitrescu; General Ioan Heruvim; Paris; Craiova; Târgovişte.

\section{INTRODUCTION}

The French leader's visit to Bucharest had very clear objectives connected to de Gaulle's Foreign Policy ideas of promoting the independence of the nation-state over political regimes. He was a responsible and staunch supporter of interaction between Eastern and Western Europe, a topic that concerned the entirety of Europe, and he had already made the first step in this direction in 1967 in Poland where the result did not live up to his expectations as the Polish political regime did not believe as much in his theory. His visit to Bucharest was even more unexpected as Nicolae Ceauşescu was planning to take advantage of his moment of glory in international affairs and once again express his opposition to Moscow's policies. France had intended to organize this visit in the same year as the one to Poland, but the Six-Day-War between Israel and the neighbouring states of Jordan, Syria and Egypt forced them to postpone it (Mâță 2011, 185).

The general demonstrated his unmatched oratory skills at the Great National Assembly in Bucharest when he spoke of "the historical friendship between the French and Romanian people, as well as the two countries ending the two-bloc system in a united Europe" (Leșu 2013). His visit to Romania took place at the same time as the student occupation protests of May 68 which were sweeping through France from Sorbonne to the Latin Quarter, culminating in the general strike that almost halted France's economy.

As a result, Charles de Gaulle shortened his stay in Romania by one day due to worries regarding the situation in his home country, but also because he had been able to get back in touch with his former colleagues from the Special Military School after almost a quarter of a century: generals Polihron Dumitrescu and Ioan Heruvim.

\footnotetext{
${ }^{1}$ Corresponding author: gabriel.degeratu@valahia.ro
} 


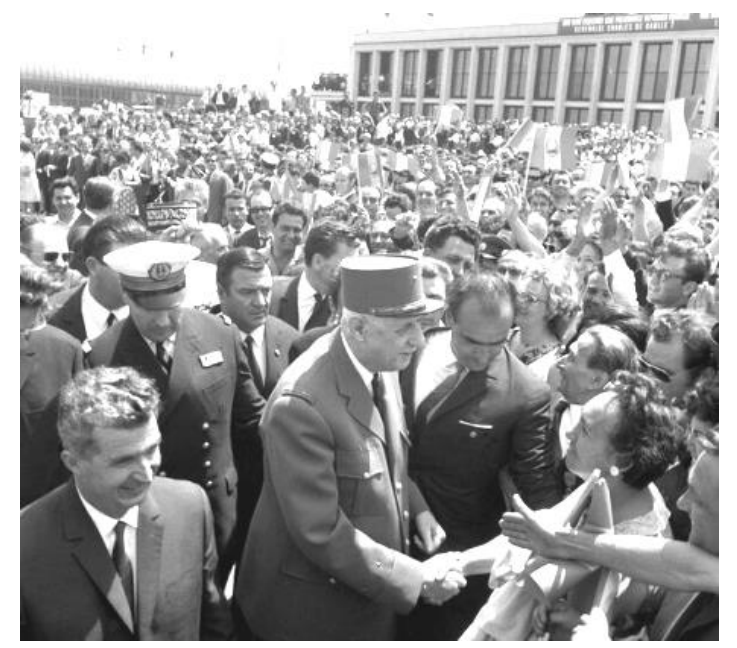

Figure 1. May 14, 1968. General Charles de Gaulle is welcomed to Romania by Nicolae Ceaușescu and an enthusiastic spectator

(source: https://www1.agerpres.ro/flux-documentare/2015/11/22/documentar-125-de-ani-de-la-nasterea-generaluluicharles-de-gaulle-presedinte-al-frantei-1959-1969--11-32-13)

\section{A HISTORIC OFFICIAL SALUTE AND THE SECRET MEETING}

An exceptional historic political Romanian-French event takes place on 16 May 1968 in Craiova in the People's Park: General Charles de Gaulle, famous in the Second World War, known as "Colonel Motor", steps out of the presidential car, raises his arm and starts to politely address surrounding people. While doing so, he looks around as if to find someone until he notices the people accompanying him, and "walking in a military manner and saluting, he stopped in front of a person he clearly recognized, the Romanian general Polihron Dumitrescu, and quickly paid him his respects in French" (Roșulescu 2011). A military service member, Charles de Gaulle was on an official visit to Romania as the president of France, but he could not forget his personal reason behind this trip. This was an unusual event for the French and Romanian people gathered in the area close to the Debarcader restaurant, but for the escort unit in charge of security, this was no chance event, but something that had been in the making for at least a year since it was announced that de Gaulle, a French general, would be the one to initiate the official salute and render honors to a Romanian general.

The two generals had been good colleagues and friends back at the Military School of Paris between 1922-1924 when Polihron Dumitrescu was de Gaulle's class president. At such military schools, it was customary for students to salute and render honors to their class president so Charles de Gaulle simply did what he used to do four and a half decades before on seeing his superior. After regrouping at Vila Jianu, the French president gave his memorable speech in front of 100,000 people at the sensational meeting that took place in the Administrative Palace Square. The Moorish dining room at Minerva restaurant would be the last destination from the official itinerary of that day.

The meeting had apparently unforeseen events, similar to what had happened in the People's Park earlier that day. Close to nine o'clock, General Charles de Gaulle left the meeting despite those attending being convinced that he was only temporarily away due to a health problem or fatigue, but the official personnel knew the truth. "A few minutes later he was on Ulm Street, on the east side of the city, in general Polihron Dumitrescu's house (his former house that he received back all fixed, refurnished, etc. with this occasion in mind)" (Rezeanu 2008, 10-12). The only person to bear witness to the almost two-hour long discussion between the two generals was Polihron Dumitrescu's French wife. She had respected the suggestions from the Department of State Security, the secret police agency of the Socialist Republic of Romania, to not talk about the hard times they had fallen on between the end of World War II and 1968. In return, the representatives of the communist regime in Romania promised the Dumitrescu family that they could keep the house and all the furniture even after President Charles de Gaulle left - a promise they kept. 
The president's room at Vila Jianu had a considerably long bed in an area where there were no windows for security reasons. "To help the general rest, a special double bed was built, $2.20 \mathrm{~m}$ in length due to his height. The French presidents and his personnel stayed at the villa for a short rest and a private breakfast. (...) The French sent us a recording of the failed assassination attempt that had taken place a few years before. To make sure all unwanted incidents could be avoided, the bedroom was moved from the one with a view towards Mihai Viteazul Street where there was still visibility to one inside. Full attention" (Gigea-Gorun 2001, 96).

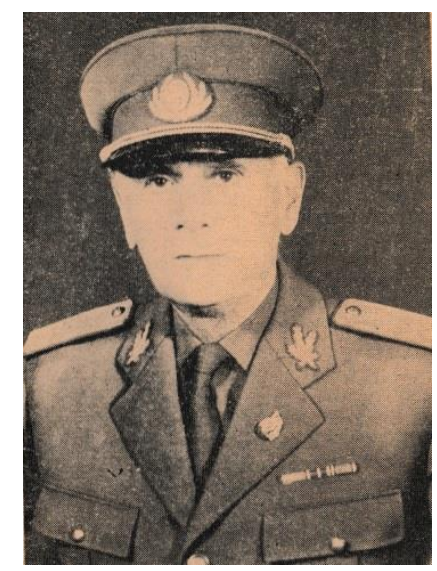

Figure 2. Major-general Polihron Dumitrescu

(source: Polihron Dumitrescu, Answering my calling, „Ascultând chemarea”, Editura Militară Publishing House, Bucharest, 1968, p.2)

\section{MEMORIES UNDER THE CHINDIA TOWER}

A day later, on 17 May 1968, general Charles de Gaulle and Nicolae Ceauşescu arrived at The Royal Court of Târgovişte where he met another former classmate from the famous Special Military School of Saint-Cyr, general Ioan Heruvim, a war veteran. The atmosphere was festive with men playing horns on the medieval ruins of the royal court. The French president stated that "I feel very happy to be at Târgovişte and that I can visit so many places that confirm the Romanian people's origin. I bring you the French salute. Long live Târgovişte! Long live Romania" and left the following message in the guest book of the County Museum: "Honour and happiness for Târgovişte".

He was profoundly affected by both extremely emotional meetings with his former classmates Ioan Heruvim and Polihron Dumitrescu. He was aware of the historic importance of this event after more than four decades since military school. He was a head of state, but in a delicate situation back in his country due to the social crisis in France from May 1968 which led to his shortening the trip. The other two Romanians were in very similar delicate situations, even if the details were very different. The two generals' identities were completely unknown in their towns, "celebrated but unknown Romanian general" (Roșulescu 2011) applied to both of them. They had both finished the School of Infantry, the Bucharest War College and the Special Military School of Saint-Cyr where they met Charles André Joseph Marie de Gaulle. After World War II, many superior officers who fought on the Eastern Front were treated with disdain.

We can imagine that they may have exchanged old jokes from their time together as young infantry officers in training at the Special Military School of Saint-Cyr. Dumitrescu as the class president had good results in his studying and military training, a situation that may suggest his true high intellect. They could have exchanged questions and answers about each other's military career and families. What is certain is that both Polihron and loan kept in mind the advice they had received from the Department of State Security about not discussing their military and social downfall after 1945, something that Charles must have already been well acquainted with. The fact that the French president had to shorten his visit to Romania due to the serious events happening in Paris led to Oltenia-style jokes in the press such as "during Charles de Gaulle's visit at Craiova, he also stopped 
in Bucharest" confirmed by Petre Gigea-Gorun². This was what happened during the first visit of a French president to our country, the general known worldwide as "colonel motor", a nickname that can be analyzed and understood in two ways.

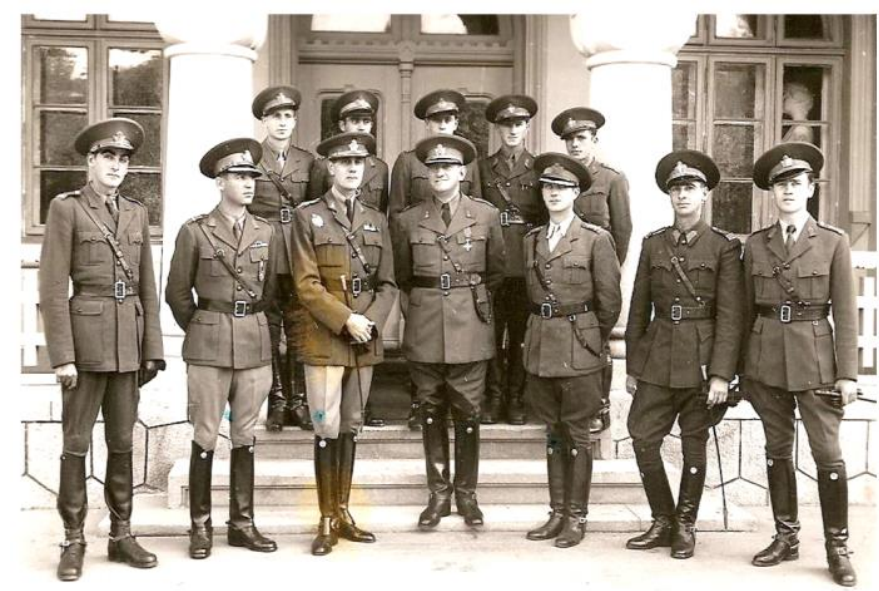

Figure 3. Colonel loan Heruvim, Knight of the Order of Michael the Brave, commander at the School of Cavalry in Târgovişte, 1945

(source: Cornel Mărculescu, Dora Dalles Middle School Bucşani, Dâmbovita County https://www.facebook.com/photo.php?fbid=10154324218281308\&set=pb.742336307.-2207520000..\&type=3)

\section{“COLONEL MOTOR”, TANK COMMANDER FOR FRANCE}

Making use of his long and interesting military experience, Charles de Gaulle published many books on military theory such as The Enemy's House Divided in 1924 or The Edge of The Sword in 1932. "I had already participated at a few conferences about the art of war, such as the one at Sorbonne. But in January 1933, Hitler became the Reich leader. From there on, things only rapidly got out of control. No one else was presenting any suggestions to handle the situation so I felt obliged to reach out to the public and present my own project. But because the situation was bound to have repercusions, I was already expecting to end up in the limelight one day. It was difficult for me to assume this risk after respecting the official military ideology for 25 years" (De Gaulle 1969, 11-12). He published Towards a Professional Army in 1934 and France and Her Army in 1938, the latter leading to a serious argument with Marshal Pétain. De Gaulle criticized the outdated war of position carried out up until that time and, six years later in his second book from his series of four, the future general and president emphasized the strategic role of the art of war, as well as a sound education of capable military leaders with a strategic vision. In practice, de Gaulle was referring to the need to create a professional army with armed corps that could combine fire power and quick movement and be capable of initiative and quick offence.

He was a strong believer in the role of tanks and proper coordination in the military which attracted the favors of General Guderian ${ }^{3}$, the creator of the strongest German force of armored warfare. This happened at a time when Colonel Émile Mayer was removed after criticizing the French Armed Forces and expressing different, but brilliant military theories such as the fact that the defense strategy at Maginot would not be enough to win the war. De Gaulle had already embraced the theory of a concentrated war of movement and armed warfare with tanks and cannons when in 1937 he was given the command of the $507^{\text {th }}$ tank regiment in Metz. On 3 September 1939, France declared war

\footnotetext{
2 Petre Gigea-Gorun, born 31 March 1930, was a Romanian minister, dignitary and diplomat between 1960-1989, who authored 39 books of memoirs, monographs, epigrams, poetry and literature. He was mayor of the city of Craiova and Governor of Romania at the World Bank and the International Monetary Fund. In 1984, as Minister of Finance of Romania, he received the „Best negotiator of the year” Award of Excellence from Euromoney. Between 1986 and 1989 he was Ambassador Extraordinary and Plenipotentiary to France. When President Charles de Gaulle visited Craiova in 1968, Petre Gigea-Gorun was the Vicepresident of the People's Council of Dolj county and one of the main organizers of the visit.

${ }^{3}$ Heinz Wilhelm Guderian, (17 June 1888 - 14 May 1954) was a German general during World War II, the "father" of the "blitzkrieg" approach. He continued his father's military career and after Germany's loss in World War I, he became an expet in tanks and armed corps. Hitler appointed him Inspector General of Armoured Troops in 1944, but demoted him one year later due to differences in military strategy. He died in 1954 and was burried at Goslar.
} 
on Germany and de Gaulle took over command of the fifth army's tank force and received his nickname of "Colonel Motor".

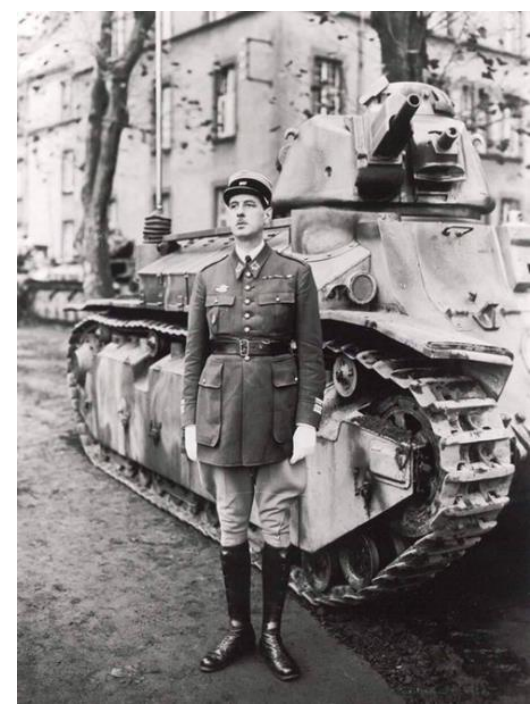

Figure 4. Charles de Gaulle standing next to a D2, 1937 "Colonel Motor" (source: Die Welt Wasilij, Saizev https://www.facebook.com/wasiwot/posts/938529639887464)

\section{“COLONEL MOTOR”, MOTORIST FOR ROMANIA}

"Colonel Motor" has another meaning for our country as de Gaulle was the one to bring the first automobile to Romania and help build this industry through Dacia in collaboration with Renault. Romania was already manufacturing off-road vehicles in Câmpulung Muscel since 1957, but it was looking to expand into the automotive industry. De Gaulle visited Mioveni where the Uzina de Autoturisme would be inaugurated after signing the contract in September 1966. After signing the contract, Renault agreed to let Romanian engineers and workers first build a car prototype before the official inauguration date. At first, the prototype was supposed to be a Renault 16, but in the end a Renault 8 model was chosen and called Dacia 1100. After the French president's visit in May, "the production of Dacia 1100, a model licensed under Renault 8, starts on 20 August 1968. It is a rearengined rear-wheel-drive small car. The first automobile that drove out of the factory was a present for the president of the Socialist Republic of Romania, Nicolae Ceauşescu. According to the contract, Renault provided all the parts needed for this model, and Dacia handled the assembly line" (Dacia Clasic, n.d.).

Before visiting the Dacia factory, he witnessed the Oltcit factory venture in Craiova, a moment of great enthusiasm in the Oltenia region that we are reminded of through the following poem: "Somewhere close to Craiova/ Where leeks grow straight/ And the man from Oltenia/ Is smart from birth./ A strange metal vehicle/ Is about to be born/ From the renowned Gallic rooster/ And the lady dog from Oltenia. People from Oltenia are confused/And they start wondering/ Will their new car/ Bark or crow?" (Detailing Workshop 2019). A year after the visit, General de Gaulle was not the president of France anymore, however, the projects continued as both Renault and Citroën wanted to continue expanding into the Comecon market. Production started at the Oltcit factory in Craiova at the end of June 1977 and was completed in 1980 . There was a possibility to obtain a license for a French plane - the MIRAGE-F, but this could not be completed as France refused to allow the production of high grade military technology in a country part of the Warsaw Treaty as it violated CoComCoordinating Committee for Multilateral Export Controls regulations imposed on state members of NATO. These regulations restricted the list of nuclear, military and civilian embargo for communist states. Despite this, the negotiations concerning the production of planes in Romania that took place during de Gaulle's presidential term resulted in obtaining the rights to produce the ALOUETTE III 316B helicopter in 1970 (Mâță 2011, 145-146). 


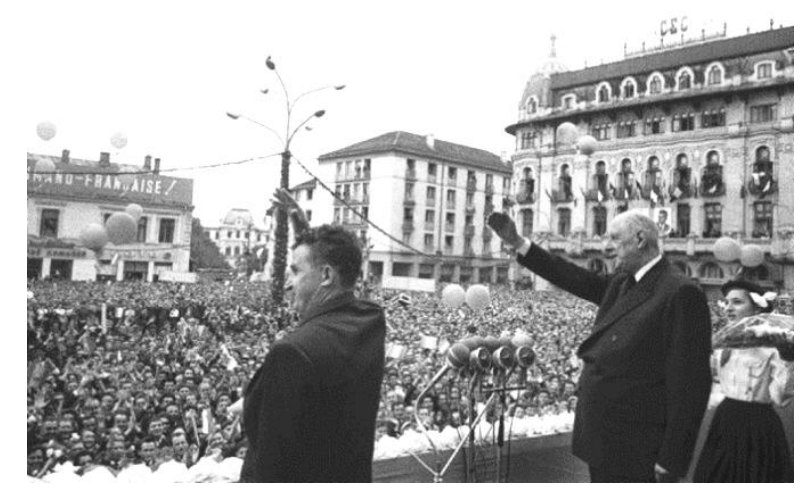

Figure 5. May 16, 1968. Nicolae Ceaușescu and Charles de Gaulle greeting people in Craiova city center (source: http://vladimirrosulescu-istorie.blogspot.com/2011_10_03_archive.html)

\section{A COMMON DENOMINATOR: THE SPECIAL MILITARY SCHOOL OF SAINT-CYR}

Charles de Gaulle was the second son of a devoutly traditional patriotic middle-class RomanCatholic family known for historians and writers. He was passionate about military life and studied at Saint-Cyr where, in 1913, he joined the infantry regiment led by colonel Philippe Pétain as a young second lieutenant. De Gaulle was a young intelligent soldier, hardworking and eager in his military career, a brilliant mind with great self-confidence and remarkable courage. During the First World War, he fought in the Battle of Verdun where he was wounded three times and spent two years and eight months as a war prisoner despite his five attempts to escape. After a short visit to Poland as part of a military mission, a year of teaching at Saint-Cyr and a two-year training course at the École Supérieure de Guerre ("Superior War School"), he was promoted by Marshal Pétain in 1925. When the Second World War commenced, de Gaulle was commanding the French fifth army's tank force. In May 1940, he temporarily took over command of the fourth Armoured Division. He maintained his rank of division commander until the end of his life.

He had the opportunity to apply his theories about armed corps and tank power during the battles of Montcornet (17 May 1940) and Abbeville (27 May - 4 June 1940). He was commended as "an admirable spirited and courageous leader" (Agerpres 2020) and wrote his memoirs in his book "The Complete War Memoirs of Charles de Gaulle".

Polihron Dumitrescu attended the Infantry Military School between 1911 and 1913 and was promoted from second lieutenant to lieutenant, and eventually captain when Romania entered World War I in 1917. In 1921 he attended the Superior War School in Bucharest for one year, after which he was sent to finish his studies at the Superior War School in Paris between 1922 and 1924. He was promoted to major and then later, during the reign of Carol II of Romania, he was promoted to lieutenant colonel in 1933 and colonel in 1937.

He became division commander in 1943 and later Vice Chief of Staff of the Third Army, Commanding Officer Infantry of the $21^{\text {st }}$ Infantry Division, Director of Supreme Military Education of the Ministry of War, General Officer Commanding of the $21^{\text {st }}$ Infantry Division and lastly Deputy General Officer Commanding of the Capital Military Command. He was awarded the Order of the Star of Romania in 1945 and retired on 9 August 1947. The general wrote his memoirs and published them in 1997 after the fall of the communist regime (Roșulescu 2011).

loan Heruvim was awarded the Order of Michael the Brave, class three by royal decree nr. 1888/12 October 1944 as commander of Regiment 11 Roşiori. He became commander at the School of Cavalry in Târgovişte where he brilliantly led the cavalry officers and Academy Professors to form the new cavalry elite of Romania with astonishing results in battle and equitation. A street connected to Viforâta village, close to Dealu Monastery where Mihai the Brave's head rests, takes it name from the general. He also received post-mortem the title of honorary citizen of the city of Târgovişte, together with others such as artists Vasile Blendea and Gheorghe Petrașcu, actors Tony Bulanda and Mihai Popescu, the writer Radu Petrescu, professor Cezar Spineanu, the engineer Constantin 
Tzitzeclis and the traditional and popular folk music singer Ileana Sărăroiu (Târgoviște Town Hall, n.d.). Neither he, nor his family published any book of memoirs.

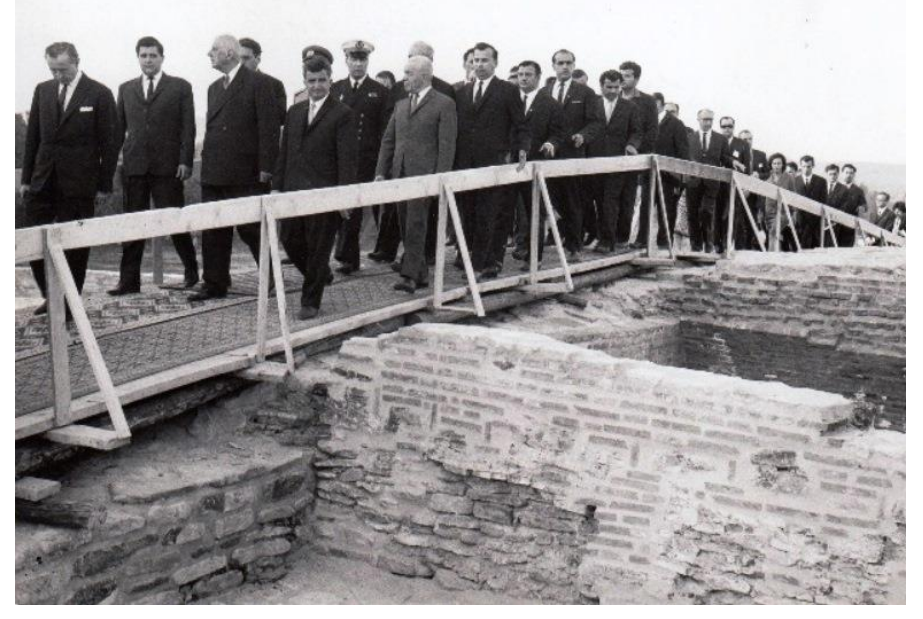

Figure 6. May 17, 1968. General Charles de Gaulle at the Royal Court of Targoviste

(source: https://www.comunismulinromania.ro/index.php/14-18-mai-1968-vizita-lui-charles-de-gaulle-in-romania-atatin-capitala-cat-si-in-orasul-craiova/)

\section{PARIS-CRAIOVA-TÂRGOVIȘTE MILITARY ITINERARY - CONCLUSIONS}

The itinerary of General Charles de Gaulle's visit to Romania was created while keeping in mind the two meetings with his former classmates, Polihron Dumitrescu and loan Heruvim, otherwise Craiova, Târgovişte, Slatina or Ploieşti would not have been part of it.

A visit to Piteşti and Colibași-Mioveni to visit the new Dacia factory for automobiles had already been taken into account and from there to Bucharest.

The French president's wish and actions completely changed the two generals' lives as Romanian authorities were forced to rescue them from the dismal conditions they had been placed in by the communist regime. I commend de Gaulle's honesty and sense of responsibility as through his salute, he was able to still pay his respects to Polihron Dumitrescu, a superior student from their time at Saint-Cyr. This gesture born of nostalgia after four and a half decades of not having seen his "superior" classmate (Roșulescu 2011) proved his sense of honour and real dignity.

This was the first and last reunion of the three generals due to their advancing age and other events. In 1969, Charles de Gaulle was replaced by Georges Pompidou and never visited Romania again. His Romanian colleagues were unable to leave the country and visit him due to travel restrictions imposed by the communist regime.

The important thing was that the military itinerary Paris-Craiova-Târgovişte was a success and Charles de Gaulle managed to achieve all his objectives during his visit to Romania.

\section{REFERENCES}

Agerpres. 2020. "General Charles de Gaulle, President of France 1959-1969". https://www1 .agerpres.ro/flux-documentare/2015/11/22/documentar-125-de-ani-de-la-nastereageneralului-charles-de-gaulle-presedinte-al-frantei-1959-1969--11-32-13. Accesed February 14, 2021.

Dacia Clasic, n.d. "History". https://daciaclasic.ro/istoric-3/. Accesed February 12, 2021.

de Gaulle, Charles. 1969. The Complete War Memoirs of Charles de Gaulle. Bucharest: Editura Politică Publishing House. 
Detailing Workshop. 2019. "Talking to the diplomat and economist Petre Gigea about Oltcit - Oltcit and general Charles de Gaulle's visit to Romania". Interview by Malva Detailing. July 4, 2019. Video 0:00-1:00. https://www.youtube.com/channel/UCHY44bG4laoc3TY3blBlgOg/search? query=Oltcit+si+vizita+generalului+Charles+de+Gaulle+in+Romania. Accesed February 14, 2021.

Dumitrescu, Polihron. 1968. Answering my calling. Bucharest: Editura Militară Publishing House.

Gigea-Gorun, Petre. 2001. People and events from Craiova. Craiova: Scrisul Românesc Publishing House.

Leșu, Georgiana. 2013. Charles de Gaulle's official visit to Bucharest, 14-18 May 1968", IICMER, May 18, 2013. https://www.iiccmer.ro/ 2013

Mâță, Dan Constantin. 2011. France-Romania relations between 1964-1968. Dialogue in the years of relaxation. Iași: „Alexandru loan Cuza” University Publishing House.

Rezeanu, Paul. President de Gaulle walked in a military manner in Craiova. Magazin istoric no. 5/2008. https://magazinistoric.ro/2008-2/mai-2008/.

Roșulescu, Vladimir. 2011. Charles de Gaulle visiting Craiova in 1968. History, October 3, 2011. http://vladimirrosulescu-istorie.blogspot.com/2011/10/charles-de-gaulle-la-craiova-1968.html

Târgoviște Museums, n.d. "History". http://muzeetargoviste.ro/generalul-charles-de-gaullepresedintele-republicii-franceze-la-targoviste/. Accesed February 11, 2021.

Târgoviște Town Hall, n.d. "Honorary citizens" http://www.pmtgv.ro/cetateni.html. Accesed February 12, 2021. 